reserves : death ensues when the sugar available for combustion is exhausted, and this occurs the earlier the larger the amount of protoplasm present. Working with Bramley's Seedling apples from three different soils, F. Kidd and C. West have shown that the nature of the soil has a marked influence on the nitrogen content of the fruit, and hence on its keeping quality. In general, specimens from silt soil survive much longer than those from fen or gravel soil, at storage temperatures of both $\mathrm{I}^{\circ} \mathrm{C}$. and $8^{\circ} \mathrm{C}$. At about the latter tomperature it was found possiblo to double the storage life by storing in an atmosphere of 9.2 per vent. carbon dioxide and 11.8 per cent. oxygen instead of in air. The apples from the silt soil have a low nitrogen content but a high sucrose content, those from fenland a high nitrogen and a low sucrose content, whilst those from gravel have a low content of both constituents: their keeping qualities agree with the inference given above that the life of an apple deponds on the demands the living protoplasm makes upon the sugar stores. The latter and the acid present in the fruit appear to be the sole source of respirable material. Dcath of the fruit stored at $1^{\circ} \mathrm{C}$. is accompanied by a browning of tho flesh, a condition known as 'internal breakdown': in its early stages, its respiration is increased whilst the acidity decreases rapidly; but in the final stage all respiration coases. Stored at $8^{\circ} \mathrm{C}$., wastago is caused by disease, 'fungal rot,' and not by internal breakdown.

The chemical changes occurring in fruit on storage are not exactly the same in different typos: thus although the respiratory processes of pears as well as apples depend on the sucrose and acid content, yet the softening occurring on ripening and storage, due to breakdown of the coll-wall and loss of pectin, is much more rapid in pears stored at $12^{\circ} \mathrm{C}$. and $4^{\circ} \mathrm{C}$., although at $1^{\circ} \mathrm{C}$. the process is less retarded in the apple (A. M. Emmett). Caution must then be exercised in applying the knowledge obtained from experiments on one type of fruit to another : optimum storage conditions will vary slightly from fruit to fruit and even from one type of the same fruit to another, although certain general principles will doubtless hold good in the majority of cases. This is well exemplified by an investigation of the same authors into the effieiency of different types of store, in which they found that varicty plays an important part in the determination of optimum storage conditions. Thus the Newton Wonder, which is very rosistant to internal breakdown, has a longer storage life the lower the temperature, at any rate to $30^{\circ} \mathrm{F}$, whilst the King Pippin, very susceptible to this form of deterioration, stores best at $40^{\circ} \mathrm{F}$. When the storage lifo is ended by 'superficial scald,' and not by 'internal breakdown," wrapping the fruit in oiled paper wrappers has a marked effect in prolonging it.

The problems of storage as affecting ships have boon investigated by A. J. M. Smith. The chief difficulty is to obtain an efficient cqualisation of temperature throughout the fruit, even when air is foreod through the cargo. The sirmplest plan appears to be to apply tho rofrigeration at the top of the cargo, which is so arranged as to have vertical air spaces between the cases of fruit: in this way the distance to be travelled by the cold air is minimised and full advantage taken of its gravitational tendency to move downwards.

This brief account gives an insight into the type of work carried out by the Food Investigation Board. The ultimate result of these and similar resoarches is clearly to improve the food supply of a nation which relies for the major part on food products brought from overseas.

\section{The Centenary of Berthelot.}

M ARCELLIN BERTIIELOT was born in Paris on Oct. 25, 1827, and thakentenary of his birth was celebrated by a squif of fumptuous functions and by the inauguratjod an enterprise which is to form a pormanent ffindial to one of the most eminent of the parch ghernts. For some time past committees hate been foourso of formation through. out France and in sowe sixty foreign countries for the collection of th funds required for carrying out a scherue for erecting and endowing in Paris a Maison de la Chimie associated with the name of Borthelot; tho sum of about sixteen million francs has been thus collected and, during last week, some six hundred foreign delegates assembled in Paris to take part in the celebration of the centenary.

The proceedings began with a reception at the Sorbonne on the evening of Sunday, Oct. 23, by M. Charléty, the rector of the University of Paris. On Monday morning, in the presence of representativos of the French Government, a museum of apparatus and manuscripts relating to Berthelot was opened at the Faculty of Pharmacy by Prof. Radet; the visitors were next received at the Colloge de France by M. Croizet; after speeches by the president of the (xorman Chemical Society, Prof. Schlenk, and Prof. Bogert, of Columbia University, Berthelot's former laboratories and apparatus were inspected. Tater, a memorial tablet was unveiled on the wall of Bortholot's early residence, 113 Rue Saint Martin, and speeches were made by M. Boujou, Préfet de la Seine.

The chief meeting was held in the large amphitheatro of the Sorbonne on the evening of Oct. 24 ; discourses wore pronounced by Prof. Ch. Moureu on the work of Berthelot, and by Prof. Lacroix, sccretary of the Academy of Sciences; M. Georges Lecomte, diroctor of the Académic française; M. Gley, president of the Academy of Medicine; M. Wéry, president of the Academy of Agriculture; M. Hodza, Minister of Education for Crechoslovakia; and by M. Paul Painlove. Addresses wore presented on behalf of numerous academic bodies; it is indicative of the widespread interest in the celebration that the first addresses handed in were those from Abyssinia and Afghanistan.

A commomoration ceremony took place at the Panthéon on 'Tuesday morning, Oct. 25, when speeches were made by $M$. Raymond Poincaré, and by $M$. Galliarclo, Minister of Forcign Affairs of the Argentine Ropublic. This was followed by a lunch in the Galérie des Batailles at Versailles, which was attended by some 1200 guests, and discourses were delivered by $M$. Herriot, Minister of Education; Prof. Amé Pictet, of the University of Geneva; and M. Lunatcharsky, Minister of Education to the Union of Socialist Soviet Republics.

On Wednesday morning, Oct. 26, the foundationstono of the new House of Chemistry was laid in the Place d'Téna by M. Herriot; M. Donat-Agache, president of the French Society of Chemical Industry; M. Zumeta, the Venczuelan Minister; and Prof. Frnst Cohen, of Utrecht, spoke, and the party adjourned for lunch to the Chateau belonging to the 'rench Acaderny at Chantilly, where discourses were pronounced by M. Lecomte, director of the French Academy, and Prof. H. E. Armstrong. In the evening tho delegates were received by the President of the Republic, M. Gaston Doumergue, at the Palais de l'Elysée.

It is proposed to issuc a commemorative volume giving a full account of the proceedings of the Berthelot centenary colobrations.
W. J. P. 